\title{
Survival of microencapsulated probiotic Lactobacillus paracasei LBC-1e during manufacture of Mozzarella cheese and simulated gastric digestion
}

\author{
F. Ortakci, ${ }^{*}$ † J. R. Broadbent, ${ }^{*}$ W. R. McManus, ${ }^{*}$ and D. J. McMahon ${ }^{\star 1}$ \\ *Western Dairy Center, Utah State University, Logan 84322-8700 \\ †Department of Food Engineering, Faculty of Agriculture, Ataturk University, Erzurum 25240, Turkey
}

\begin{abstract}
An erythromycin-resistant strain of probiotic Lactobacillus paracasei ssp. paracasei LBC-1 (LBC-1e) was added to part-skim Mozzarella cheese in alginatemicroencapsulated or free form at a level of $10^{8}$ and $10^{7}$ $\mathrm{cfu} / \mathrm{g}$, respectively. Survival of LBC-1e and total lactic acid bacteria (LAB) was investigated through the pasta filata process of cheese making (in which the cheese curd was heated to $55^{\circ} \mathrm{C}$ and stretched in $70^{\circ} \mathrm{C}$-hot brine), followed by storage at $4^{\circ} \mathrm{C}$ for $6 \mathrm{wk}$ and simulated gastric and intestinal digestion. This included incubation in $0.1 M$ and $0.01 M \mathrm{HCl}, 0.9 \mathrm{M} \mathrm{H}_{3} \mathrm{PO}_{4}$, and a simulated intestinal juice consisting of pancreatin and bile salts in a $\mathrm{pH} 7.4$ phosphate buffer. Some reductions were observed in both free and encapsulated LBC-1e during heating and stretching, with encapsulated LBC-1e surviving slightly better. Changes in total LAB losses during heating and stretching did not reach statistical significance. During storage, a decrease was observed in total LAB, but no statistically significant decrease was observed in LBC-1e. Survival during gastric digestion in $\mathrm{HCl}$ was dependent on the extent of neutralization of $\mathrm{HCl}$ by the cheese, with more survival in the weaker acid, in which $\mathrm{pH}$ increased to 4.4 after cheese addition. The alginate microcapsules did not provide any protection against the $\mathrm{HCl}$. It is interesting that survival of the encapsulated LBC-1e was greater during incubation in $\mathrm{H}_{3} \mathrm{PO}_{4}$ than in the $\mathrm{HCl}$ gastric juices. Proper selection of simulated gastric digestion media is important for predicting the delivery of probiotic bacteria into the human intestinal tract. Neither free nor encapsulated LBC-1e was affected by incubation in the pancreatinbile solution. Based on the level of probiotic bacteria in cheese needed to provide a health benefit and its survival during simulated gastric digestion, as determined in this study, it should theoretically be possible to lower the amount that needs to be ingested in cheese by up
\end{abstract}

Received February 27, 2012.

Accepted July 8, 2012.

${ }^{1}$ Corresponding author: donald.mcmahon@usu.edu to a factor of $10^{3}$ compared with other fermented dairy foods or when consumed as supplements.

Key words: microencapsulation, probiotic, Mozzarella, cheese, gastric

\section{INTRODUCTION}

Probiotics are live microorganisms that, when administered in adequate amounts $\left(10^{6}\right.$ to $\left.10^{7} \mathrm{cfu} / \mathrm{g}\right)$, confer a health benefit on the host (FAO/WHO, 2002). Probiotics may be consumed either as a food component or as a nonfood preparation. Foods containing such bacteria fall within the functional foods category, and these are described as foods claimed to have a positive effect on health. However, for a probiotic bacterium to provide a benefit to human health, it must fulfill several criteria. It must have good technological properties so that it can be manufactured and incorporated into food products without losing viability and functionality. It must maintain that viability through storage to the end of the shelf life of the food and should not create unpleasant flavors or textures. It must also survive passage through the upper gastrointestinal (GI) tract and arrive alive at its site of action, and it must be able to function in the gut environment (Mattila-Sandholm et al., 2002).

Yogurts and other fermented milks have been used as delivery systems for probiotic cultures, although cheese has been suggested as a better carrier because of better survival of the probiotic culture during storage and through the GI tract (Ong et al., 2006; Sharp et al., 2008). Various cheeses have been investigated, including Cheddar (Stanton et al., 1998; Phillips et al., 2006), low-fat Cheddar (Sharp et al., 2008), Gouda (Gomes et al., 1998), cottage cheese (Heller, 2001), Turkish white cheese (Kasimoglu et al., 2004), Argentinean cheese (Bergamini et al., 2006), and Kaşar (Ozer et al., 2008). Whether probiotic bacteria can survive in cheeses that are exposed to a severe heat treatment (such as the pasta filata process used during manufacture of Mozzarella cheese) has not been reported. It is also difficult to properly enumerate probiotic bacteria in cheese by using selective media when high numbers of other lactic 
acid bacteria (LAB) are present (Oberg et al., 2011) unless the probiotic culture contains a biomarker that allows its specific enumeration (Sharp et al., 2008).

The $\mathrm{pH}$ and reduced oxygen levels of cheese make it suitable for long-term survival of probiotic bacteria (Boylston et al., 2004; Phillips et al., 2006). In contrast, lower $\mathrm{pH}$ and higher oxygen levels in a liquid matrix, such as fermented milks and yogurt, may not maintain sufficient numbers (i.e., $>10^{7}$ viable cell $/ \mathrm{g}$ ) of the probiotic bacteria (such as some strains of Bifidobacterium spp.) through to the end of the shelf life (Gardiner et al., 1999; Shah, 2000). It has also been suggested that the high buffering capacity and lipid content of cheese provide protection to probiotic bacteria in the GI tract (Phillips et al., 2006). Thus, cheese could deliver viable probiotics in sufficient numbers to provide therapeutic effects through the entire shelf life (Burns et al., 2008).

To exert a health benefit via action in the distal ileum and colon, probiotic bacteria must survive passage through the esophagus, a highly acidic stomach, and an alkaline small intestine (Naidu et al., 1999). Losses of up to 6 to $9 \mathrm{log} \mathrm{cfu} / \mathrm{g}$ of probiotic bacteria in simulated gastric digestion have been reported (Sabikhi et al., 2010; Ortakci, 2010), depending on the bacterial strain and testing conditions. Immobilization of bacteria within an encapsulating matrix has been investigated as a means of reducing cell injury or loss and improving their survival in foods (Kailasapathy, 2006; Muthukumarasamy and Holley, 2006; Ozer et al., 2009; Ortakci, 2010; Brinques and Ayub, 2011) and during gastric digestion (Chandramouli et al., 2004; Picot and Lacroix, 2004; Muthukumarasamy et al., 2006; Ding and Shah, 2009; Pimentel-González et al., 2009; Ortakci, 2010; Brinques and Ayub, 2011).

To be effective, capsules should maintain integrity in the foodstuff and during digestion and passage though the GI tract, after which they should break down and release their contents. Different types of encapsulating materials have been used to trap probiotic bacteria. The most common is alginate because it has the benefits of being nontoxic, easy to form into a gel, and readily available (Ding and Shah, 2009). Mixing an aqueous Na-alginate-bacterial suspension with vegetable oil can create a water-in-oil emulsion that, when treated with Ca, solidifies into beads (Sheu and Marshall, 1993) of 0.025 to $2 \mathrm{~mm}$ in diameter, depending on shear rate (Krasaekoopt et al., 2003).

Reports have been conflicting on the effectiveness of alginate encapsulation of probiotic bacteria to increase survival in simulated gastric juice (SGJ). Hansen et al. (2002) found no improvement in the survival of acidsensitive bifidobacteria incubated in SGJ at $\mathrm{pH} \mathrm{2,4}$, or 6 when using alginate microspheres with diameters of $<100 \mu \mathrm{m}$. Krasaekoopt et al. (2004) also reported no increased survival of alginate-encapsulated Bifidobacterium bifidum in HCl-SGJ at $\mathrm{pH}$ 1.55. In contrast, Muthukumarasamy et al. (2006), who encapsulated 5 different strains of Lactobacillus reuteri in $2 \%$ alginate using small $(\sim 40-\mu \mathrm{m})$ or large $(\sim 2-\mathrm{mm})$ capsules, reported a protective effect in SGJ at pH $1.5(0.08 \mathrm{M}$ $\mathrm{HCl}, 0.2 \% \mathrm{NaCl}$ ). Using the same SGJ, Ortakci (2010) observed a similar effect with $\sim 2$-mm alginate capsules containing Lactobacillus acidophilus ATCC 4356, with a $\sim 3$-log reduction in encapsulated bacteria compared with no survival (>7-log reduction) of free Lb. acidophilus ATCC 4356 under the same conditions.

This study investigated the survival of the probiotic Lactobacillus paracasei during the manufacture and storage of low-moisture part-skim Mozzarella cheese, and whether encapsulating the bacteria in alginate microcapsules would increase their survival. Some question remains regarding whether the reported benefits of using cheese to deliver probiotic cultures is an inherent function of the cheese or a consequence of how survival in the human digestive tract is simulated and measured. To elucidate such survival using cheese as a delivery mechanism, the cheese was added to simulated gastric juice of various acidic conditions (and a simulated intestinal juice) and then bacterial survival was measured.

\section{MATERIALS AND METHODS}

\section{Materials}

Lactobacillus paracasei ssp. paracasei LBC-1e, an erythromycin-resistant derivate (Broadbent et al., 2004) of the probiotic strain LBC-1 (Cargill, Waukesha, WI), was obtained from the culture collection of Jeffrey Broadbent (Utah State University, Logan). Streptococcus thermophilus starter culture TS-10C was donated by DSM Food Specialties USA Inc. (Eagleville, PA). Sodium alginate, Tween-80, erythromycin, and bile salts were purchased from Sigma-Aldrich Co. (St. Louis, MO); Elliker's agar, de Man, Rogosa, and Sharpe (MRS) broth, and agar were from Becton Dickinson (Franklin Lakes, NJ); peptone was from EMD Chemicals Inc. (Gibbstown, NJ); pepsin was from Mallinckrodt Baker Inc. (Phillipsburg, NJ); pancreatin was from Spectrum Chemical Mfg. Co. (New Brunswick, NJ); and corn oil (Western Family Foods Inc., Portland, OR) was from a local supermarket. The $\mathrm{CaCl}_{2} \cdot \mathrm{H}_{2} \mathrm{O}, \mathrm{HCl}$, $\mathrm{NaCl}, \mathrm{NaH}_{2} \mathrm{PO}_{4}$, and $\mathrm{Na}_{2} \mathrm{HPO}_{4}$ were analytical reagent grade. Double-strength chymosin rennet (Maxiren) was from DSM Food Specialties USA Inc., and fluorescein isothiocyanate (FITC) was from Sigma-Aldrich Co. The SYTO 9 used was a component of a LIVE/DEAD BacLight bacterial viability kit (Invitrogen, Carlsbad, 
CA). Microscope slides were from Mercedes Medical (Sarasota, FL), and the Taylor Lube petroleum gel was from Haynes Manufacturing Co. (Westlake, OH).

\section{Bacterial Growth Conditions}

Working cultures of LBC-1e were prepared from frozen stocks stored at $-70^{\circ} \mathrm{C}$ by sequential transfer twice into MRS broth containing $3 \mu \mathrm{g} / \mathrm{mL}$ of erythromycin, in which the cultures were incubated anaerobically at $37^{\circ} \mathrm{C}$ for $18 \mathrm{~h}$. After incubation overnight, the media containing cells were centrifuged at $4,250 \times g$ for 10 min at $4^{\circ} \mathrm{C}$, following which the supernatant was removed and the cells were further washed twice $(4,250 \times$ $g$ for $10 \mathrm{~min}$ at $4^{\circ} \mathrm{C}$ ) with sterile $0.1 \%$ (wt/vol) peptone water. The washed cells were suspended to $\sim 10^{10} \mathrm{cfu} /$ $\mathrm{mL}$ in saline-peptone water by comparing the optical density with a previously prepared standard curve $\left(\mathrm{R}^{2}\right.$ $\geq 0.9$; data not shown).

\section{Microencapsulation}

Bacterial cells were microencapsulated in alginate by the modified emulsion method of Sheu and Marshall (1993). Briefly, $200 \mathrm{~mL}$ of cell suspension $\left(\sim 10^{10} \mathrm{cfu} /\right.$ $\mathrm{mL}$ ) was mixed with $800 \mathrm{~g}$ of a $25 \mathrm{~g} / \mathrm{kg}$ Na-alginate solution with continuous stirring at $400 \mathrm{rpm}$ for $10 \mathrm{~min}$ to entrap bacteria. The alginate-culture mixture was then added dropwise through a $50-\mathrm{mL}$ sterile syringe fitted with a needle into $5 \mathrm{~kg}$ of corn oil containing $0.2 \%$ (wt/vol) Tween-80 with stirring ( $\sim 500 \mathrm{rpm})$. When the oil-alginate mixture formed an emulsion, as was evident from the increasing turbidity, a sterile 0.2 $M \mathrm{CaCl}_{2}$ solution was added immediately to polymerize the alginate and break the emulsion. After $30 \mathrm{~min}$, the Ca-alginate microcapsules formed were collected by vacuum filtration through Whatman \#4 filter paper (Whatman International, Maidstone, UK), washed twice in $0.2 \mathrm{M} \mathrm{CaCl}_{2}$, and then stored in peptone-saline solution at $4^{\circ} \mathrm{C}$ until use.

\section{Mozzarella Cheese Manufacture}

Fresh bovine milk was obtained from Utah State University's George B. Caine Dairy Research and Teaching Center (Wellsville, UT) and was standardized to a protein:fat ratio of 1.2 and pasteurized at $73^{\circ} \mathrm{C}$ for $15 \mathrm{~s}$ in the Gary Haight Richardson Dairy Products Laboratory. Two $16-\mathrm{kg}$ portions of milk were warmed to $35^{\circ} \mathrm{C}$ in small stainless steel vessels, $1 \mathrm{~g}$ of starter culture was added to each, and the milk was ripened for $60 \mathrm{~min}$. The milk was then renneted by adding 4 $\mathrm{mL}$ of chymosin. The milk was stirred for $\sim 2 \mathrm{~min}$, and the adjunct probiotic culture was quickly added as ei- ther $10 \mathrm{~g}$ of broth containing free LBC-1e cells $(\sim 1 \times$ $\left.10^{10} \mathrm{cfu} / \mathrm{g}\right)$ or $360 \mathrm{~g}$ of encapsulated LBC-1e $\left(\sim 5 \times 10^{8}\right.$ $\mathrm{cfu} / \mathrm{g})$. The milk was stirred and then allowed to coagulate. After $15 \mathrm{~min}$, the curd was cut using wire knives (16-mm spacing), healed for $10 \mathrm{~min}$, and then stirred and heated to $41^{\circ} \mathrm{C}$. With continued stirring, one-third portions of whey were removed after 15 and $35 \mathrm{~min}$, and the whey was drained down to the curd level after a further $10 \mathrm{~min}$. The curd was stirred for $10 \mathrm{~min}$ and washed with $13^{\circ} \mathrm{C}$ water to cool the curd to $22^{\circ} \mathrm{C}$; it was then drained and salted at $10 \mathrm{~g} / \mathrm{kg}$.

Each batch of curd (containing either free or encapsulated LBC-1e) was divided into three 550-g portions, and a sample was collected for bacterial enumeration. Each replicate portion of curd was stretched in an excess amount of hot $70^{\circ} \mathrm{C}$ brine (containing $50 \mathrm{~g} / \mathrm{kg}$ of $\mathrm{NaCl}$ ) for about 1 min to heat the curd to $55 \pm 1^{\circ} \mathrm{C}$ and held for $2 \mathrm{~min}$. The hot cheese was then placed in a stainless steel mold and immersed in iced brine (containing $50 \mathrm{~g} / \mathrm{kg}$ of $\mathrm{NaCl}$ and $3 \mathrm{~g} / \mathrm{kg}$ of $\mathrm{CaCl}_{2}$ ) for $2 \mathrm{~h}$. The temperature of the cheese blocks decreased to $\sim 24^{\circ} \mathrm{C}$ in $30 \mathrm{~min}, \sim 12^{\circ} \mathrm{C}$ after $1 \mathrm{~h}$, and to $6^{\circ} \mathrm{C}$ by $2 \mathrm{~h}$. Each block of cold cheese was sampled for bacterial enumeration, and then cut into 4 pieces, vacuumed packaged, and stored at $4^{\circ} \mathrm{C}$.

\section{Bacterial Enumeration}

Bacteria were enumerated from Mozzarella cheese containing free LBC-1e after mixing $25 \mathrm{~g}$ of cheese with $225 \mathrm{~mL}$ of $0.1 \%$ peptone water at $230 \mathrm{rpm}$ for 10 min (Model 400 stomacher; Seward, London, UK). For cheese containing encapsulated LBC-1e, $0.2 M$ phosphate buffer ( $\mathrm{pH} 7$ ) was used in place of peptone water to disrupt the alginate gel and release the encapsulated bacteria. Total LAB were enumerated on MRS agar with the pour-plate method and were incubated anaerobically at $37^{\circ} \mathrm{C}$ for $48 \mathrm{~h}$. The LBC-1e was selectively enumerated on MRS agar containing $3 \mu \mathrm{g} / \mathrm{mL}$ of erythromycin.

\section{Simulated Gastric Digestive}

To investigate the influence of $\mathrm{pH}$ on the survival of probiotic bacteria, sterile filtered SGJ (based on that used by Mainville et al., 2005) containing $2.0 \mathrm{~g} / \mathrm{kg}$ of $\mathrm{NaCl}$ and $0.3 \mathrm{~g} / \mathrm{kg}$ of pepsin was prepared using $\mathrm{HCl}$. To provide $\mathrm{pH}$ of the SGJ-cheese mixture similar to the physiological $\mathrm{pH}$ of the human stomach $(\sim \mathrm{pH} 1.4)$, SGJ-1 was made using $0.1 \mathrm{M} \mathrm{HCl}$ with a cheese:SGJ ratio of 1:6. For SGJ-2, the same acid concentration was used but the cheese:SGL ratio was changed to 1:4, and then to simulate physiological conditions in which further acid is secreted into the stomach after food in- 
gestion, additional $\mathrm{HCl}$ was added during incubation of the SGJ-cheese mixture to maintain $\mathrm{pH}<3$. To further test the effect of $\mathrm{pH}$ on bacterial survival and allow a greater increase in $\mathrm{pH}$ after adding the cheese, SGJ-3 was then made using $11 \mathrm{mM} \mathrm{HCl}$. An additional acid digestion test (SGJ-4) was performed using $87 \mathrm{mM}$ $\mathrm{H}_{3} \mathrm{PO}_{4}(\mathrm{pH}$ 2.0) instead of $\mathrm{HCl}$ as a comparison with the report of Sharp et al. (2008) [Sharp et al. (2008) incorrectly reported the strength of the $\mathrm{H}_{3} \mathrm{PO}_{4}$ they used as $8.7 \mathrm{mM}$.] Before adding cheese, the SGJ were tempered to $37^{\circ} \mathrm{C}$. The mixture was then stomached for $10 \mathrm{~min}$ at $230 \mathrm{rpm}$ and held at $37^{\circ} \mathrm{C}$ for up to $2 \mathrm{~h}$ with periodic shaking.

\section{Simulated Intestinal Digestive}

After treating the cheese for $60 \mathrm{~min}$ in $0.1 \mathrm{M} \mathrm{HCl}$ (SGJ-1), the mixture was converted to simulated intestinal juice (SIJ; Huang and Adams, 2004; Annan et al., 2008) by adding to $36 \mathrm{~mL}$ of the mixture $1 \mathrm{mg} /$ $\mathrm{mL}$ pancreatin and $4.5 \mathrm{~g} / \mathrm{mL}$ of bile salts suspended in phosphate buffer, and then adjusting to $\mathrm{pH} 7.4$ with 0.1 $M \mathrm{NaOH}$. The cheese-SIJ mixture was then incubated for $4 \mathrm{~h}$ at $37^{\circ} \mathrm{C}$ with periodic shaking.

\section{Microstructure}

Thin slices $(\sim 10 \times 10 \times 3 \mathrm{~mm})$ of Mozzarella cheese mounted on microscope slides were treated with $5 \mathrm{~g} / \mathrm{L}$ of FITC in an acetone:water (1:1) solution to stain for protein. The sample was rinsed twice with water and then treated with $3.34 \mathrm{~m} M$ of the SYTO 9 fluorophore. Stained samples were mounted on standard microscope slides with glycerin jelly and then examined using an inverted laser scanning confocal microscope (BioRad, Hercules, CA) with an $\mathrm{Ar} / \mathrm{Kr}$ laser that provided excitation of both FITC and SYTO 9 at a wavelength of $488 \mathrm{~nm}$. Emissions from the fluorophores were captured sequentially using filters of wavelengths 512 to $532 \mathrm{~nm}$ for SYTO 9 and $\geq 585 \mathrm{~nm}$ for FITC.

\section{Statistical Analysis}

Logarithmic reductions in bacterial numbers as a consequence of hot water stretching and chemical analysis results of both cheese samples were analyzed by one-way ANOVA and Tukey's multiple comparison test (PROC GLIMMIX; SAS Institute Inc., Cary, NC) with 3 replicates. Logarithmic reductions in bacterial numbers during storage and as a consequence of SGJ or SIJ incubation were analyzed using repeated measurement and Tukey's multiple comparison test (PROC GLIMMIX; SAS Institute Inc.) as a 2-way factorial with encapsulation as the treatment effect with 3 replicates. Significance was declared at $P \leq 0.05$.

\section{RESULTS AND DISCUSSION}

\section{Cheese Composition}

The cheeses had similar moisture of 55.5 and $55.6 \%$ and $\mathrm{pH}$ of 5.39 and 5.41, respectively, for cheese containing free or encapsulated bacteria. A slightly lower fat content (12.5 vs. $15.8 \%)$ and higher salt content $(1.88$ vs. $1.70 \%)$ were observed $(P<0.05)$ for the cheese with the encapsulated bacteria. These differences were not expected to influence bacterial survival and were assumed to relate to the presence of the alginate microcapsules during milk coagulation and curd manufacture.

As shown in Figure 1, the microcapsules containing the LBC-1e bacteria (A) were located in the serum and fat pockets that form within the curd structure as the protein matrix forms and that contract as a consequence of renneting, acid development and curd agitation, and cooking. During the hot-water stretching process, the fat droplets are then oriented into channels concomitantly with the protein matrix forming into fibrous strands (Oberg et al., 1993).

\section{Cheese Manufacture and Storage}

Initial numbers of total LAB in the cheese curd were $8.3 \times 10^{8}$ and $2.2 \times 10^{9} \mathrm{cfu} / \mathrm{g}$ for curds that contained free and encapsulated bacteria, respectively (Table 1). Included in this enumeration were the St. thermophilus starter culture and the LBC-1e probiotic culture. Addition of LBC-1e to milk had been planned to provide about $1 \times 10^{9} \mathrm{cfu} / \mathrm{g}$ of bacteria per 28 -g serving of cheese, assuming the concentration of bacteria would be 10-fold during conversion of milk into curd, with an allowance for potential loss of microcapsules by sedimentation before coagulation. The number of LBC-1e added to the milk had been estimated at $\sim 6 \times 10^{6}$ and $\sim 1 \times 10^{7} \mathrm{cfu} / \mathrm{g}$ of free and encapsulated bacteria, respectively, and the amount measured in the cheese curd was $6.6 \times 10^{7}$ and $5.4 \times 10^{8} \mathrm{cfu} / \mathrm{g}$, respectively. Thus, less loss of encapsulated bacteria occurred during the coagulation process than anticipated, and the 2 sets of cheese curd contained above the target of $3.61 \times 10^{7}$ $\mathrm{cfu} / \mathrm{g}$.

When the curd was immersed and stretched in hot water, the bacterial numbers decreased slightly (Table 1). Total LAB had mean log reductions of 0.20 and 0.40 for the control and encapsulated treatments, respectively. The extent of decrease for total LAB was not significantly different $(P=0.095)$ in the control 
Table 1. Mean microbiological counts (cfu/g) for total lactic acid bacteria (LAB) and added Lactobacillus paracasei LBC-1e (LBC-1e) in Mozzarella curd (before hot stretching) and cheese during refrigerated storage for cheese in which LBC-1e was added to milk before renneting as free (control) or alginate-encapsulated bacteria $^{1}$

\begin{tabular}{lccccc}
\hline & \multicolumn{2}{c}{ Total LAB } & & \multicolumn{2}{c}{ LBC-1e } \\
\cline { 2 - 3 } \cline { 5 - 6 } Time $(\mathrm{d})$ & Control & Encapsulated & & Control & Encapsulated \\
\hline $0^{2}$ (curd) & $8.19 \times 10^{8}$ & $1.78 \times 10^{9}$ & & $5.98 \times 10^{7}$ & $5.37 \times 10^{8}$ \\
$0^{3}$ (cheese) & $5.00 \times 10^{8}$ & $6.62 \times 10^{8}$ & & $2.11 \times 10^{7}$ & $3.16 \times 10^{8}$ \\
7 & $6.61 \times 10^{8}$ & $1.82 \times 10^{9}$ & & $2.46 \times 10^{7}$ & $3.44 \times 10^{8}$ \\
21 & $2.24 \times 10^{8}$ & $7.38 \times 10^{8}$ & & $3.75 \times 10^{7}$ & $2.55 \times 10^{8}$ \\
42 & $2.23 \times 10^{8}$ & $7.13 \times 10^{8}$ & & $3.18 \times 10^{7}$ & $2.50 \times 10^{8}$ \\
\hline
\end{tabular}

${ }^{1}$ The total LAB includes the Streptococcus thermophilus starter culture, free or encapsulated LBC-1e, respectively, and any nonstarter LAB present in the cheese.

${ }^{2}$ Before the hot stretching process of curd.

${ }^{3}$ After the hot stretching process of curd.

cheese but was in the cheese containing the encapsulated bacteria. The survival of encapsulated LBC-1e bacteria was slightly higher $(P=0.012)$ than that in cheese containing free bacteria, with log reductions of 0.25 and 0.45 , respectively.

During $42-\mathrm{d}$ storage, no decrease $(P=0.84)$ was observed in the number of either free or encapsulated LBC-1e (Table 1) in the Mozzarella cheese, as has been

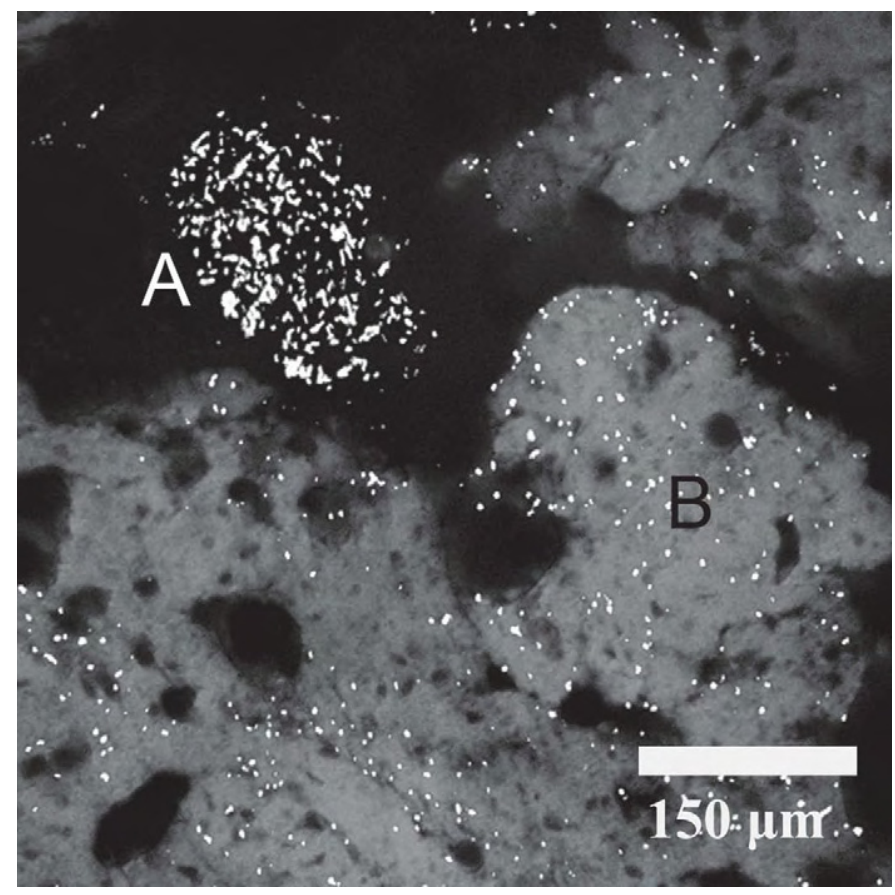

Figure 1. Laser scanning confocal micrograph of Mozzarella cheese containing alginate-encapsulated Lactobacillus paracasei LBC-1e with protein imaged using fluorescein isothiocyanate (Sigma-Aldrich Inc., Saint Louis, MO; gray), bacterial cells imaged using SYTO 9 (Invitrogen, Carlsbad, CA; white), and serum pockets and fat not being stained (black). A: Microcapsule containing LBC-1e located in a serum pocket; B: Streptococcus thermophilus starter culture distributed throughout the protein matrix. shown for Cheddar cheese storage (Stanton et al., 1998; Gardiner et al., 1999; Sharp et al., 2008). However, the total LAB numbers decreased significantly $(P<0.0001)$ during the storage period, indicating that a slow die-off of residual starter St. thermophilus bacteria occurred after the first week of refrigerated storage.

\section{Simulated Gastric Digestion}

The extent of die-off of bacteria when the cheese was incubated in HCl-based SGJ was a function of both acid concentration and the extent of neutralization of acid upon cheese addition. When cheese was incubated in SGJ-1 (0.1M HCl, pH 0.65, cheese:SGJ ratio of 1:6), the LBC-1e numbers decreased by 4.2 log after a $60-\mathrm{min}$ incubation (Table 2). Initial mean bacteria counts were $5.6 \times 10^{7}$ and $3.5 \times 10^{8} \mathrm{cfu} / \mathrm{g}$ for free and encapsulated LBC-1e, and after $1 \mathrm{~h}$ they had declined to $4.7 \times 10^{3}$ and $2.7 \times 10^{4} \mathrm{cfu} / \mathrm{g}$, respectively $(P<0.0001)$.

After adding the cheese, the $\mathrm{pH}$ of the mixture had increased to $\mathrm{pH} 1.4$, which is similar to the $\mathrm{pH}$ of the human stomach before ingestion of food. In such a harsh environment, no protection was provided by encapsulation of the bacteria in Ca-alginate. This agrees with the reports of Hansen et al. (2002) and Krasaekoopt et al. (2004) rather than that of Muthukumarasamy et al. (2006). Because protection has been observed when using large macrocapsules (Ortakci, 2010), it appears that size of the capsules influences the protective effect of alginate encapsulation. It may be that in larger $(\sim 2-$ $\mathrm{mm}$ ) capsules, a die-off of bacteria occurs in the outer regions, which are more exposed to the acid, whereas the bacteria in the inner regions are protected. This would explain the $\sim 3$-log reduction observed in macroencapsulated $L b$. acidophilus while free bacteria showed no survival (>7-log loss; Ortakci, 2010).

When a greater proportion of cheese was added (such as in SGJ-2), the $\mathrm{pH}$ of the cheese-SGJ mixture in- 
Table 2. Mean loss $(\mathrm{n}=3)$ of free (control) and encapsulated Lactobacillus paracasei LBC-1e in Mozzarella cheese after incubation in simulated gastric juice (SGJ) and simulated intestinal juice (SIJ)

\begin{tabular}{|c|c|c|c|c|c|c|c|}
\hline \multirow[b]{2}{*}{ Juice } & \multirow[b]{2}{*}{ Composition } & \multirow[b]{2}{*}{ Ratio $^{1}$} & \multirow[b]{2}{*}{ Time $(\min )$} & \multicolumn{2}{|c|}{$\mathrm{pH}$} & \multicolumn{2}{|c|}{ Loss during incubation $\left(\log _{10} \mathrm{cfu} / \mathrm{g}\right)$} \\
\hline & & & & Initial & Final & Control & Encapsulated \\
\hline SGJ-2 & $0.1 M \mathrm{HCl}^{2}$ & $1: 4$ & 120 & 0.65 & 2.3 & $1.88^{\mathrm{b}, \mathrm{x}}$ & $1.50^{\mathrm{b}, \mathrm{x}}$ \\
\hline SGJ-3 & $0.01 M \mathrm{HCl}$ & $1: 6$ & 120 & 1.5 & 4.4 & $1.03^{\mathrm{c}, \mathrm{x}}$ & $1.13^{\mathrm{b}, \mathrm{x}}$ \\
\hline SGJ-4 & $0.9 M \mathrm{H}_{3} \mathrm{PO}_{4}$ & $1: 9$ & 120 & 2.0 & 2.2 & $3.80^{\mathrm{a}, \mathrm{y}}$ & $1.05^{\mathrm{b}, \mathrm{x}}$ \\
\hline $\mathrm{SIJ}^{3}$ & Bile and pancreatin & $1: 6$ & 240 & 7.4 & 7.4 & $0^{\mathrm{d}, \mathrm{x}}$ & $0^{\mathrm{c}, \mathrm{x}}$ \\
\hline
\end{tabular}

${ }^{\mathrm{a}-\mathrm{d}}$ Means within a column with the same letters are not significantly different $(\alpha=0.05)$.

${ }^{\mathrm{x}, \mathrm{y}}$ Means within a row with the same letters are not significantly different $(\alpha=0.05)$.

${ }^{1}$ Ratio of cheese added to simulated gastric solutions.

${ }^{2}$ Additional $0.1 \mathrm{M} \mathrm{HCl}$ was added to SGJ-2 during incubation to maintain $\mathrm{pH}<2.5$.

${ }^{3}$ Survival in SIJ was determined by adding $1 \mathrm{mg} / \mathrm{mL}$ of pancreatin and $4.5 \mathrm{~g} / \mathrm{mL}$ of bile salts suspended in phosphate buffer after incubating cheese in SGJ-1 for 60 min, then adjusting pH to 7.4 with $0.1 \mathrm{M} \mathrm{NaOH}$

creased above that maintained in the stomach, primarily because of the buffering capacity of the protein and phosphate in the cheese. By periodically adding $0.1 \mathrm{M}$ $\mathrm{HCl}$ during incubation, this buffering effect was countered and the final $\mathrm{pH}$ of SGJ-2 was 2.3. Under these conditions, survival of bacteria was greater compared with that in SGJ-1, and numbers of free and encapsulated LBC-1e in SGJ-2 decreased from initial mean values of $1.5 \times 10^{7}$ and $2.6 \times 10^{8} \mathrm{cfu} / \mathrm{g}$ to $1.5 \times 10^{5}$ and $1.1 \times 10^{7} \mathrm{cfu} / \mathrm{g}$, respectively, after a 2 -h incubation $(P<0.0001)$. Again, no protection was observed on bacterial survival in SGJ-2 provided by encapsulation.

The loss of bacteria after a 2-h incubation in $11 \mathrm{mM}$ $\mathrm{HCl}$ (SGJ-3) was minimal, with $90 \%$ of LBC-1e surviving (i.e., only $\sim 1-\log$ reduction) for both free and encapsulated bacteria. Initial mean counts were 3.29 $\times 10^{7}$ and $2.55 \times 10^{8} \mathrm{cfu} / \mathrm{g}$ for free and encapsulated bacteria, respectively, and these had declined to $3.14 \times$ $10^{6}$ and $1.08 \times 10^{7} \mathrm{cfu} / \mathrm{g}$ after incubation $(P<0.0001)$. Such survival can be attributed to buffering of SGJ3 by the cheese, and it was observed that $\mathrm{pH}$ of this gastric solution increased to $\mathrm{pH} \geq 4$ within 2 min. This supports the notion that the matrix in which the bacteria are present can influence their survival, as shown by Sharp et al. (2008), and that bacteria, as a liquid culture, are not protected as effectively as when present in a semisolid matrix. This explains why Gardiner et al. (1999) found no reduction in probiotic bacteria in Cheddar cheese after a 2-h incubation in porcine gastric juice that had an initial $\mathrm{pH}$ of 2.0 and a final $\mathrm{pH}$ of 4.74. It is important in such simulated testing that the SGJ match the proper physiological conditions because bacterial survival is influenced by the $\mathrm{pH}$ (Mainville et al., 2005; Pitino et al., 2010) encountered by the probiotic bacteria when ingested.

We have shown that the buffering effect of a food that is delivering probiotic bacteria can influence bacterial survival when tested in vitro using an acid medium to simulate gastric contents of the human stomach. However, such buffering provides an artifactual result because in vivo in a healthy individual, additional acid is secreted into the stomach to maintain acidity at or below $\sim \mathrm{pH} 2$. Under such conditions, a 4-log reduction in bacterial numbers can be expected in foods with greater reductions occurring when bacteria are ingested in a nonprotected form.

When acid tolerance of LBC-1e was tested using phosphoric acid (SGJ-4) so that buffering effects of the cheese would be negated, bacteria again had very poor survival $(P<0.0001)$ in the control Mozzarella cheese containing free LBC-1e. The $\mathrm{pH}$ of SGJ-4 remained $\sim 2$ during incubation, and mean numbers of free LBC-1e fell from an initial level of $3.3 \times 10^{7} \mathrm{cfu} / \mathrm{g}$ to $2.0 \times 10^{3} \mathrm{cfu} / \mathrm{g}$ after incubation $(P<0.0001$; Table 2 ). This agrees with the report of Sharp et al. (2008), who observed a 3.8-log reduction after a 2-h incubation in SGJ-4 of a low-fat Cheddar cheese containing $L$ b. paracasei $334 \mathrm{e}$. It is interesting that greater survival was observed when the bacteria were present in cheese in encapsulated form (Table 2). Mean numbers of LBC-1e were $2.6 \times 10^{8} \mathrm{cfu} / \mathrm{g}$ before incubation and remained at $2.3 \times 10^{7} \mathrm{cfu} / \mathrm{g}$ after the 2 -h incubation $(P<0.0001)$.

The in vitro test of gastric survival using $\mathrm{H}_{3} \mathrm{PO}_{4}$ (SGJ-4) was useful to provide a buffering effect when the bacteria were present in a free form, but it was not a good test for acid tolerance of the bacteria in the alginate microcapsules. Some interaction between the $\mathrm{H}_{3} \mathrm{PO}_{4}$ and $\mathrm{Ca}$-alginate capsules possibly may have prevented penetration of acid into the capsules. As shown in SGJ-2, in which $\mathrm{HCl}$ was replenished during incubation so as to maintain acid conditions of the cheeseSGJ mixture, encapsulation was unable to provide any significant protective effect for the bacteria. 
When the cheese-SGJ-1 mixture was neutralized and bile and pancreatin were added to form SIJ, a slight increase in bacterial numbers to $4.7 \times 10^{3}$ and $2.7 \times$ $10^{4} \mathrm{cfu} / \mathrm{g}$ was observed for the free and encapsulated bacteria, respectively, probably because of resuscitation of some cells that were sublethally injured during the 1-h incubation of SGJ-1. Incubation of the cheese-SIJ mixture for $4 \mathrm{~h}$ at $37^{\circ} \mathrm{C}$ did not significantly affect survival of either free or encapsulated LBC-1e (Table 2 ), indicating a natural bile resistance of this probiotic strain.

In the present study, using cheese as a delivery system has a positive effect on survivability of the bacteria because of its buffering effect and possibly because it may provide a protective environment to the probiotic bacteria (Ruass-Madiedo et al., 2002). Compared with yogurt and other fermented milks, the higher buffering capacity of the cheese, the higher fat content, and the tight matrix may improve the survival of bacteria in the stomach and intestines (Heller, 2001). It is well known that ingesting bacteria that have been incorporated into food improves their viability during GI passage (Zárate et al., 2000; Huang and Adams, 2004). We agree with Mainville et al. (2005) on the importance of incorporating bacteria into a food matrix so that the bacteria can be protected from the harsh environment of the human digestive tract and reach their site of action in sufficiently high numbers.

The Food and Agriculture Organization of the United Nations/World Health Organization (FAO/ WHO, 2002) has made a general recommendation that a probiotic food should contain $10^{6}$ to $10^{7} \mathrm{cfu} / \mathrm{g}$ so that a 100 -g serving would provide $10^{8}$ to $10^{9} \mathrm{cfu}$ that were ingested. However, dose-response studies supporting this number are sparse; the number of probiotic bacteria that would ensure an effect has not been standardized, and this number is actually strain and effect dependent (Rowland et al., 2010). With ingestion of $10^{9} \mathrm{cfu}$ of probiotic bacteria as an isolated culture, no survival after passage through the stomach would be expected, and perhaps only $10^{2}$ cfu would be expected in a liquid or soft-gel food, such as yogurt (Sharp et al., 2008), when the $\mathrm{pH}$ is held constant during incubation in SGJ. If the probiotic culture is delivered in a hard gel, such as cheese, the expected survival after gastric passage would be $10^{5}$. Thus, by having $10^{9} \mathrm{cfu} /$ serving of a probiotic organism in cheese, 100- to 1,000fold more living cells of the bacteria would survive in the intestinal tract, where it needs to be present to have any beneficial health effect. If the aim is to deliver $10^{4}$ bacteria/g to the intestines, this could be achieved beginning with as little as $10^{6} \mathrm{cfu} / \mathrm{g}$ in cheese because only a 2-log reduction during simulated gastric digestion occurred when $\mathrm{pH}$ was maintained similarly to physiological conditions and some buffering occurs. This would have a dramatic effect on reducing the cost of producing probiotic foods.

\section{CONCLUSIONS}

Hot stretching during Mozzarella cheese manufacture caused slight log reductions of 0.4 and 0.2 in the numbers of free and encapsulated $L b$. paracasei LBC-1e, respectively. Refrigerated storage did not make any difference in the numbers of free and gel encapsulated LBC-1e; however, during storage, the total LAB numbers in both cheeses (predominantly the starter St. thermophilus bacteria) decreased significantly. Encapsulation did not increase the survival in SGJ containing $\mathrm{HCl}$. Survival of LBC-1e was dependent on $\mathrm{pH}$ of the SGJ-cheese mixture. We observed mean log reductions of 4.0, 1.5, and 1.1 when the final $\mathrm{pH}$ of SGJ reached $\mathrm{pH} 1.4,2.3$, and 4.4 , respectively. This shows the importance of selecting the proper conditions for simulating gastric digestion and when comparing various research results using SGJ. It was unexpected that alginate encapsulation increased the survival of LBC-1e in $\mathrm{H}_{3} \mathrm{PO}_{4}$ SGJ, although the reason for this is not known.

\section{ACKNOWLEDGMENTS}

Financial support for F. Ortakci was provided by a scholarship from the Turkish Higher Educational Council (Ankara, Turkey) and Ataturk University to support his visit to Utah State University. We thank David Irish (Western Dairy Center, Utah State University) for support during cheese manufacture and Xin Dai (College of Agriculture, Utah State University) for performing statistical analysis. The use of trade names in this publication does not imply endorsement by Utah State University of the products named or criticism of similar ones not mentioned. This research was supported by the Utah Agricultural Experiment Station, Utah State University, and is approved as journal paper no. 8403.

\section{REFERENCES}

Annan, N. T., A. D. Borza, and L. T. Hansen. 2008. Encapsulation in alginate-coated gelatin microspheres improves survival of the probiotic Bifidobacterium adolescentis $15703 \mathrm{~T}$ during exposure to simulated gastro-intestinal conditions. Food Res. Int. 41:184-193.

Bergamini, C. V., E. R. Hynes, and C. A. Zalazar. 2006. Influence of probiotic bacteria on the proteolysis profile of a semi-hard cheese. Int. Dairy J. 16:856-866.

Boylston, T., C. Vinderola, H. Ghoddusi, and J. Reinheimer. 2004. Incorporation of bifidobacteria into cheeses: Challenges and rewards. Int. Dairy J. 14:375-387.

Brinques, G. B., and M. A. Z. Ayub. 2011. Effect of microencapsulation on survival of Lactobacillus plantarum in simulated gastrointestinal conditions, refrigeration, and yogurt. J. Food Eng. 103:123-128. 
Broadbent, J. R., S. Gummalla, J. E. Hughes, M. E. Johnson, S. A. Rankin, and M. A. Drake. 2004. Overexpression of Lactobacillus casei D-hydroxyisocaproic acid dehydrogenase in Cheddar cheese. Appl. Environ. Microbiol. 70:4814-4820.

Burns, P., F. Patrignani, D. Serrazanetti, G. C. Vinderola, J. Reinheimer, R. Lanciotti, and M. E. Goerzioni. 2008. Probiotic Crescenza cheese containing Lactobacillus casei and Lactobacillus acidophilus manufactured with high-pressure homogenized milk. J. Dairy Sci. 91:500-512.

Chandramouli, V., K. Kailasapathy, P. Peiris, and M. Jones. 2004. An improved method of microencapsulation and its evaluation to protect Lactobacillus spp. in simulated gastric conditions. J. Microbiol. Methods 56:27-35.

Ding, W. K., and N. P. Shah. 2009. An improved method of microencapsulation of probiotic bacteria for their stability in acidic and bile conditions during storage. J. Food Sci. 74:M53-M61.

FAO/WHO (Food and Agriculture Organization of the United Nations/World Health Organization). 2002. Guidelines for the evaluation of probiotics in food. FAO/WHO Joint Working Group Report. Accessed Aug. 29, 2012. ftp://ftp.fao.org/es/esn/food/ wgreport2.pdf.

Gardiner, G., C. Stanton, P. B. Lynch, J. K. Collins, G. Fitzgerald, and R. P. Ross. 1999. Evaluation of cheddar cheese as a food carrier for delivery of a probiotic strain to the gastrointestinal tract. J. Dairy Sci. 82:1379-1387.

Gomes, A. M. P., M. M. Vieira, and F. X. Malcata. 1998. Survival of probiotic microbial strains in a cheese matrix during ripening: Simulation of rates of salt diffusion and microorganism survival. J. Food Eng. 36:281-301.

Hansen, L. T., P. M. Allan-Wojtas, Y. L. Jin, and A. T. Paulson. 2002. Survival of Ca-alginate microencapsulated Bifidobacterium spp. in milk and simulated gastrointestinal conditions. Food Microbiol. 19:35-45.

Heller, K. J. 2001. Probiotic bacteria in fermented foods: Product characteristics and starter organisms. Am. J. Clin. Nutr. 73:374S379S.

Huang, Y., and M. C. Adams. 2004. In vitro assessment of the upper gastrointestinal tolerance of potential probiotic dairy propionibacteria. Int. J. Food Microbiol. 91:253-260.

Kailasapathy, K. 2006. Survival of free and encapsulated probiotic bacteria and their effect on the sensory properties of yoghurt. LWT-Food Sci. Technol. 39:1221-1227.

Kasimoglu, A., M. Goncuoglu, and S. Akgun. 2004. Probiotic white cheese with Lactobacillus acidophilus. Int. Dairy J. 14:1067-1073.

Krasaekoopt, W., B. Bhandari, and H. Deeth. 2003. Evaluation of encapsulation techniques of probiotics for yoghurt. Int. Dairy J. 13:3-13.

Krasaekoopt, W., B. Bhandari, and H. Deeth. 2004. The influence of coating materials on some properties of alginate beads and survivability of microencapsulated probiotic bacteria. Int. Dairy J. 14:737-743.

Mainville, I., Y. Arcand, and E. R. Farnworth. 2005. A dynamic model that simulates the human upper gastrointestinal tract for the study of probiotics. Int. J. Food Microbiol. 99:287-296.

Mattila-Sandholm, T., P. Myllarinen, R. Crittenden, G. Mogensen, R. Fonden, and M. Saarela. 2002. Technological challenges for future probiotic foods. Int. Dairy J. 12:173-182.

Muthukumarasamy, P., P. Allan-Wojtas, and R. A. Holley. 2006. Stability of Lactobacillus reuteri in different types of microcapsules. J. Food Sci. 71:M20-M24.

Muthukumarasamy, P., and R. A. Holley. 2006. Microbiological and sensory quality of dry fermented sausages containing alginatemicroencapsulated Lactobacillus reuteri. Int. J. Food Microbiol. 111:164-169.

Naidu, A. S., W. R. Bidlack, and R. A. Clemens. 1999. Probiotic spectra of lactic acid bacteria (LAB). Crit. Rev. Food Sci. Nutr. 39:13-126.
Oberg, C. J., W. McManus, and D. J. McMahon. 1993. Microstructure of Mozzarella cheese during manufacture. Food Struct. 12:251258

Oberg, C. J., L. V. Moyes, M. J. Domek, C. F. Brothersen, and D. J. McMahon. 2011. Survival of probiotic adjunct cultures in cheese and challenges in their enumeration using selective media. J. Dairy Sci. 94:2220-2230.

Ong, L., A. Henriksson, and N. P. Shah. 2006. Development of probiotic cheddar cheese containing Lactobacillus acidophilus, Lb. casei, Lb. paracasei and Bifidobacterium spp. and the influence of these bacteria on proteolytic patterns and production of organic acid. Int. Dairy J. 16:446-456.

Ortakci, F. 2010. Improving the health benefits of probiotic bacteria by microencapsulation. MS Thesis. Atatürk Univ., Erzurum, Turkey.

Ozer, B., H. A. Kirmaci, E. Senel, M. Atamer, and A. Hayaloglu. 2009. Improving the viability of Bifidobacterium bifidum BB-12 and Lactobacillus acidophilus LA-5 in white-brined cheese by microencapsulation. Int. Dairy J. 19:22-29.

Ozer, B., Y. S. Uzun, and H. A. Kirmaci. 2008. Effect of microencapsulation on viability of Lactobacillus acidophilus LA-5 and Bifidobacterium bifidum BB-12 during Kasar cheese ripening. Int. J. Dairy Technol. 61:237-244.

Phillips, M., K. Kailasapathy, and L. Tran. 2006. Viability of commercial probiotic cultures (L. acidophilus, Bifidobacterium sp., L. casei, L. paracasei and L. rhamnosus) in cheddar cheese. Int. J. Food Microbiol. 108:276-280.

Picot, A., and C. Lacroix. 2004. Encapsulation of bifidobacteria in whey protein-based microcapsules and survival in simulated gastrointestinal conditions and in yoghurt. Int. Dairy J. 14:505-515.

Pimentel-González, D. J., R. G. Campos-Montiel, C. Lobato-Calleros, R. Pedroza-Islas, and E. J. Vernon-Carter. 2009. Encapsulation of Lactobacillus rhamnosus in double emulsions formulated with sweet whey as emulsifier and survival in simulated gastrointestinal conditions. Food Res. Int. 42:292-297.

Pitino, I., C. L. Randazzo, G. Mandalari, A. Lo Curto, R. M. Faulks, Y. Le Marc, C. Bisignano, C. Caggia, and M. S. J. Wickham. 2010. Survival of Lactobacillus rhamnosus strains in the upper gastrointestinal tract: Static and dynamic digestion systems. Food Microbiol. 27:1121-1127.

Rowland, I., L. Capurso, K. Collins, J. Cummings, N. Delzenne, O. Goulet, F. Guarner, P. Marteau, and R. Meier. 2010. Current level of consensus on probiotic science. Gut Microbes 1:436-439.

Ruass-Madiedo, P., J. Hugenholtz, and P. Zoon. 2002. An overview of the functionality of exopolysaccharides produced by lactic acid bacteria. Int. Dairy J. 12:163-171.

Sabikhi, L., R. Babu, D. K. Thompkinson, and S. Kapila. 2010. Resistance of microencapsulated Lactobacillus acidophilus LA1 to processing treatments and simulated gut conditions. Food Bioprocess Technol. 3:586-593.

Shah, N. P. 2000. Probiotic bacteria: Selective enumeration and survival in dairy foods. J. Dairy Sci. 83:894-907.

Sharp, M. D., D. J. McMahon, and J. R. Broadbent. 2008. Comparative evaluation of yogurt and low-fat Cheddar cheese as delivery media for probiotic Lactobacillus casei. J. Food Sci. 73:M375M377.

Sheu, T. Y., and R. T. Marshall. 1993. Microencapsulation of lactobacilli in calcium alginate gels. J. Food Sci. 54:557-561.

Stanton, C., G. Gardiner, P. B. Lynch, J. K. Collins, G. Fitzgerald, and R. P. Ross. 1998. Probiotic cheese. Int. Dairy J. 8:491-496.

Zárate, G., A. P. Chaia, S. González, and G. Oliver. 2000. Viability and $\beta$-galactosidase activity of dairy propionibacteria subjected to digestion by artificial gastric and intestinal fluids. J. Food Prot. 63:1214-1221. 